\title{
Combined Effects of Alzheimer Risk Variants in the CLU and ApoE Genes on Ventricular Expansion Patterns in the Elderly
}

\author{
Florence F. Roussotte, ${ }^{1,3}$ Boris A. Gutman, ${ }^{3,4}$ Sarah K. Madsen, ${ }^{3,4}$ John B. Colby, ${ }^{1}$ \\ and Paul M. Thompson ${ }^{1,2,3,4,5}$ for the Alzheimer's Disease Neuroimaging Initiative* \\ ${ }^{1}$ Department of Neurology, and 2 Department of Psychiatry, Semel Institute, David Geffen School of Medicine, University of California, Los Angeles, Los \\ Angeles, California 90095, ${ }^{3}$ Imaging Genetics Center, and ${ }^{4}$ Departments of Neurology, and ${ }^{5}$ Psychiatry, Radiology, Engineering, Pediatrics, and \\ Ophthalmology, Keck School of Medicine, University of Southern California, Los Angeles, California 90033
}

The $\mathrm{C}$ allele at the rs 11136000 locus in the clusterin $(C L U)$ gene is the third strongest known genetic risk factor for late-onset Alzheimer's disease (LOAD). A recent genome-wide association study of LOAD found the strongest evidence of association with $C L U$ at rs 1532278 , in high linkage disequilibrium with rs 11136000 . Brain structure and function are related to the CLU risk alleles, not just in LOAD patients but also in healthy young adults. We tracked the volume of the lateral ventricles across baseline, 1-year, and 2-year follow-up scans in a large sample of elderly human participants ( $N=736$ at baseline), from the Alzheimer's Disease Neuroimaging Initiative, to determine whether these $C L U$ risk variants predicted longitudinal ventricular expansion. The rs 11136000 major C allele-previously linked with reduced $C L U$ expression and with increased risk for dementia-predicted faster expansion, independently of dementia status or ApoE genotype. Further analyses revealed that the $C L U$ and $A p o E$ risk variants had combined effects on both volumetric expansion and lateral ventricle surface morphology. The rs 1532278 locus strongly resembles a regulatory element. Its association with ventricular expansion was slightly stronger than that of rs 11136000 in our analyses, suggesting that it may be closer to a functional variant. Clusterin affects inflammation, immune responses, and amyloid clearance, which in turn may result in neurodegeneration. Pharmaceutical agents such as valproate, which counteract the effects of genetically determined reduced clusterin expression, may help to achieve neuroprotection and contribute to the prevention of dementia, especially in carriers of these $C L U$ risk variants.

Key words: ApoE; brain aging; clusterin; genetics; neuroimaging; ventricular expansion

\section{Introduction}

Dynamic changes in the lateral ventricles of the brain are a powerful indicator of the rate of brain atrophy as we age and represent

\section{Received Dec. 16, 2013; revised March 1, 2014; accepted April 1, 2014.}

Author contributions:F.F.R. and P.M.T. designed research; F.F.R. and P.M.T. performed research; B.A.G. and J.B.C. contributed unpublished reagents/analytic tools; F.F.R., B.A.G., S.K.M., J.B.C., and P.M.T. analyzed data; F.F.R. and P.M.T. wrote the paper.

F.F.R. was supported, in part, by a postdoctoral Fellowship from the A. P. Giannini Foundation. This work was additionally supported by National Institutes of Health (NIH) Grants R01 MH097268 and R01 AG040060 to P.M.T. Data collection and sharing for this project were funded by the Alzheimer's Disease Neuroimaging Initiative (ADNI; National Institutes of Health Grant U01 AG024904). ADNI is funded by the National Institute on Aging, the National Institute of Biomedical Imaging and Bioengineering, and through generous contributions from the following: Alzheimer's Association; Alzheimer's Drug Discovery Foundation; BioClinica; Biogen Idec Inc.; Bristol-Myers Squibb Company; Eisai Inc.; Elan Pharmaceuticals; Eli Lilly and Company; F. Hoffmann-La Roche Ltd and its affiliated company Genentech; GE Healthcare; Innogenetics, N.V.; IXICO Ltd.; Janssen Alzheimer Immunotherapy Research \& Development, LLC; Johnson \& Johnson Pharmaceutical Research \& Development LLC; Medpace; Merck \& Co.; Meso Scale Diagnostics, LLC; NeuroRx Research; Novartis Pharmaceuticals Corporation; Pfizer Inc.; Piramal Imaging; Servier; Synarc Inc.; and Takeda Pharmaceutical Company. The Canadian Institutes of Health Research is providing funds to support ADNI clinical sites in Canada. Private sector contributions are facilitated by the Foundation for the National Institutes of Health (www.fnih.org). The grantee organization is the Northern California Institute for Research and Education, and the study is coordinated by the Alzheimer's Disease Cooperative Study at the University of California, San Diego. ADNI data are disseminated by the Laboratory of Neuro Imaging at the University of Southern California. This research was also supported by NIH Grants P30 AG010129 and K01 AG030514.

*Data used in the preparation of this article were obtained from the Alzheimer's Disease Neuroimaging Initiative (ADNI) database (adni.loni.usc.edu). As such, the investigators within the ADNI contributed to the design and implementation of ADNI and/or provided data, but most of them did not participate in this analysis or the writing of an accumulation of diffuse brain tissue loss with very high effect sizes (Hua et al., 2013). Ventricular enlargement occurs in normal aging, but Alzheimer's disease (AD) leads to larger ventricular volumes (Carmichael et al., 2007a) and faster expansion rates (Carmichael et al., 2007b).

The $\mathrm{C}$ allele at the rs11136000 locus in the clusterin (CLU) gene is the third strongest known genetic risk factor for late onset Alzheimer's disease after the apolipoprotein E $\varepsilon 4$ allele (ApoEع4) and the much rarer variant in TREM2 (Rajagopalan et al., 2013). ApoE- $\varepsilon 4$ increases AD risk up to fourfold per risk allele carried, and the rs $11136000 \mathrm{C}$ allele confers a 1.16 greater odds of the development of AD (Bertram and Tanzi, 2010). This CLU risk allele is carried by $\sim 88 \%$ of Caucasians (Harold et al., 2009; Lambert et al., 2009). Intriguingly, the more prevalent form of this variant-the major $\mathrm{C}$ allele-confers greater $\mathrm{AD}$ risk. In a sense, the less commonly carried version of CLU-the minor $\mathrm{T}$ allele-may be considered a protective form of the gene.

this report. A complete listing of ADNI investigators can be found at: http://adni.loni.usc edu/wp-content/uploads/how_to_apply/ADNI_Acknowledgement_List.pdf.

The authors declare no competing financial interest.

Correspondence should be addressed to Dr. Paul Thompson, Professor of Neurology, Psychiatry, Radiology, Engineering, Pediatrics, and Ophthalmology, Keck School of Medicine, University of Southern California, 2001 North Soto Street, Los Angeles, CA 90033. E-mail: pthomp@usc.edu.

DOI:10.1523/JNEUROSCI.5236-13.2014

Copyright $\odot 2014$ the authors $\quad 0270-6474 / 14 / 346537-09 \$ 15.00 / 0$ 
The rs11136000 variant was identified simultaneously in two independent genome-wide association studies (GWASs; Harold et al., 2009; Lambert et al., 2009), and was later replicated in other GWAS (Wijsman et al., 2011) and case-control studies (Carrasquillo et al., 2010; Jun et al., 2010), though the newest GWAS found the strongest evidence of association with $C L U$ at rs1532278 (Naj et al., 2011). The rs11136000 polymorphism identified in the first two seminal studies became a candidate variant in many subsequent investigations, which uncovered important associations. The $\mathrm{C}$ allele is linked with faster cognitive decline in presymptomatic stages of $\mathrm{AD}$ progression (Thambisetty et al., 2013), and lower memory scores in both AD patients and healthy elderly individuals (Pedraza et al., 2014). It predicts hyperactivation of brain regions related to memory processes during a functional magnetic resonance imaging working memory task, even in healthy young adults (Lancaster et al., 2011). Young healthy carriers of this risk allele also show altered patterns of functional and structural connectivity, characterized by reduced coupling between hippocampus and prefrontal cortex during memory processing (Erk et al., 2011) and lower white matter integrity in multiple brain regions (Braskie et al., 2011). Thus, we hypothesized that rs11136000, and the more recently identified rs1532278 variant, would be associated with ventricular expansion patterns, independently of dementia status.

Here, we tested this primary hypothesis by tracking the volumes of the lateral ventricles across 2 years, in a large sample of elderly participants from the Alzheimer's Disease Neuroimaging Initiative (ADNI). We then created $3 \mathrm{D}$ maps of ventricular expansion associated with these variants-after controlling for age, sex, and dementia status. As we recently reported a strong association between ApoE- $\varepsilon 4$ and the trajectory of ventricular enlargement both in dementia and normal aging (Roussotte et al., 2014), we conducted additional analyses to investigate the combined effects of CLU and ApoE genotypes on ventricular expansion.

\section{Materials and Methods}

Subjects. Data used in this study were obtained from the ADNI database. The primary goal of the ADNI has been to test whether serial MRI, positron emission tomography, other biological markers, and clinical and neuropsychological assessments can be combined to measure the progression of mild cognitive impairment (MCI) and early AD. The determination of sensitive and specific markers of very early $\mathrm{AD}$ progression is intended to help researchers and clinicians to develop new treatments and monitor their effectiveness, and to decrease the time and cost of clinical trials. All ADNI studies are conducted according to the Good Clinical Practice guidelines, the Declaration of Helsinki, and U.S. 21 CFR Part 50 (Protection of Human Subjects), and Part 56 (Institutional Review Boards). Written informed consent was obtained from all participants before protocol-specific procedures were performed. To avoid the known effects of population stratification on genetic analysis (Lander and Schork, 1994), we included only non-Hispanic Caucasian subjects identified by self-report and confirmed by multidimensional scaling analysis (Stein et al., 2010). The ADNI cohort included the following three diagnostic groups: subjects with $\mathrm{AD}$, subjects with amnestic MCI, and healthy elderly control (CON) subjects (Aisen et al., 2010). Our final analysis comprised 736 individuals (average age $\pm \mathrm{SD}, 75.52 \pm 6.79$ years; 436 males and 300 females) including $173 \mathrm{AD}, 358 \mathrm{MCI}$, and 205 CON subjects at baseline. More demographic and clinical details about participants, broken down by CLU and ApoE genetic subgroups, are provided in Tables 1 and 2 (for rs 11136000 and rs1532278, respectively).

Genotyping. ADNI participants were genotyped using the Illumina 610-Quad BeadChip. We analyzed two common (C > T, minor allele frequency: $\mathrm{T}=0.385$ for rs11136000; and $\mathrm{T}=0.281$ for $\mathrm{rs} 1532278$ ) single nucleotide polymorphisms (SNPs) in the CLU gene, for associa-
Table 1. Demographic and clinical data by genetic subgroups (CLU at rs11136000)

\begin{tabular}{|c|c|c|c|c|}
\hline rs11136000 & $\mathrm{CC}$ & $\mathrm{CT}$ & TT & Total \\
\hline \multicolumn{5}{|l|}{0 APOE $\epsilon 4$ allele } \\
\hline $\mathrm{N}_{0}$ & $147(58)$ & $175(78)$ & $51(19)$ & 373 (155) \\
\hline $\mathrm{Age}_{0}$ & $76.67 \pm 7.00$ & $76.50 \pm 6.75$ & $74.86 \pm 7.21$ & $76.34 \pm 6.92$ \\
\hline \multicolumn{5}{|l|}{$\mathrm{Dx}_{0}$} \\
\hline CON subjects & 57 & 71 & 23 & 151 \\
\hline MCl subjects & 65 & 74 & 23 & 162 \\
\hline AD subjects & 25 & 30 & 5 & 60 \\
\hline $\mathrm{N}_{12}$ & $118(41)$ & 149 (69) & $46(17)$ & 313 (127) \\
\hline $\mathrm{N}_{24}$ & $92(38)$ & $116(54)$ & $33(12)$ & 241 (104) \\
\hline \multicolumn{5}{|l|}{$1 \mathrm{APOE} \in 4$ allele } \\
\hline $\mathrm{N}_{0}$ & $103(40)$ & $134(53)$ & $45(18)$ & 282 (111) \\
\hline $\mathrm{Age}_{0}$ & $74.86 \pm 6.13$ & $76.11 \pm 6.20$ & $74.91 \pm 7.39$ & $75.46 \pm 6.38$ \\
\hline \multicolumn{5}{|l|}{$\mathrm{Dx}_{0}$} \\
\hline CON subjects & 20 & 22 & 8 & 50 \\
\hline MCI subjects & 55 & 74 & 24 & 153 \\
\hline AD subjects & 28 & 38 & 13 & 79 \\
\hline $\mathrm{N}_{12}$ & $88(35)$ & 109 (43) & $40(17)$ & $237(95)$ \\
\hline $\mathrm{N}_{24}$ & $71(25)$ & $84(31)$ & 28 (14) & $183(70)$ \\
\hline \multicolumn{5}{|l|}{2 APOE $\epsilon 4$ alleles } \\
\hline $\mathrm{N}_{0}$ & $33(15)$ & $33(13)$ & $15(6)$ & 81 (34) \\
\hline $\mathrm{Age}_{0}$ & $73.09 \pm 6.22$ & $71.33 \pm 6.32$ & $70.80 \pm 7.14$ & $71.95 \pm 6.43$ \\
\hline \multicolumn{5}{|l|}{$\mathrm{Dx}_{0}$} \\
\hline CON subjects & 2 & 1 & 1 & 4 \\
\hline MCI subjects & 16 & 17 & 10 & 43 \\
\hline AD subjects & 15 & 15 & 4 & 34 \\
\hline $\mathrm{N}_{12}$ & $28(12)$ & $31(13)$ & $13(4)$ & $72(29)$ \\
\hline $\mathrm{N}_{24}$ & $21(11)$ & $23(8)$ & $11(2)$ & $55(21)$ \\
\hline \multicolumn{5}{|l|}{ Total } \\
\hline $\mathrm{N}_{0}$ & $283(113)$ & 342 (144) & $111(43)$ & $736(300)$ \\
\hline $\mathrm{Age}_{0}$ & $75.60 \pm 6.70$ & $75.85 \pm 6.65$ & $74.33 \pm 7.34$ & $75.52 \pm 6.79$ \\
\hline \multicolumn{5}{|l|}{$\mathrm{Dx}_{0}$} \\
\hline CON subjects & 79 & 94 & 32 & 205 \\
\hline MCl subjects & 136 & 165 & 57 & 358 \\
\hline AD subjects & 68 & 83 & 22 & 173 \\
\hline $\mathrm{N}_{12}$ & $234(88)$ & $289(125)$ & $99(38)$ & $622(251)$ \\
\hline $\mathrm{N}_{24}$ & 184 (74) & $223(93)$ & $72(28)$ & 479 (195) \\
\hline
\end{tabular}

Data are sample sizes (number of women) or mean $\pm \mathrm{SD} . \mathrm{N}_{0}, \mathrm{~N}_{12}$, and $\mathrm{N}_{24}$ indicate sample sizes at baseline, 12 month follow-up, and 24 month follow-up, respectively; $\mathrm{Age}_{0}$ and $\mathrm{Dx}_{0}$ indicate baseline ages and diagnoses.

tion with longitudinal ventricular expansion and ventricular surface morphology, independently of dementia status. The two variants were in very high linkage disequilibrium $\left(r^{2}=0.966, \mathrm{D}^{\prime}=0.983\right)$ in the ADNI sample.

ApoE genotyping was performed separately, on DNA samples obtained from subjects' blood, using an $A p o E$ genotyping kit, as described in http://www. adni-info.org/Scientists/Pdfs/ADNI_GeneralProceduresManual.pdf (also see http://www.adni-info.org for detailed information on blood sample collection, DNA preparation, and genotyping methods). The ApoE gene is polymorphic, with the following three major isoforms: ApoE2 ( $\varepsilon 2$ allele), ApoE3 ( $\varepsilon 3$ allele), and ApoE4 ( $\varepsilon 4$ allele). In our analyses that controlled for $A p o E$ status, $A p o E$ genotype was coded as 0,1 , and 2 for the presence of 0,1 , and 2 ApoE- $\varepsilon 4$ adverse alleles, respectively.

Image acquisition, correction, and preprocessing. Participants were scanned with a standardized MRI protocol developed for this cohort (Leow et al., 2006; Jack et al., 2008). Briefly, high-resolution structural brain MRI scans were acquired at 58 sites across North America, using 1.5 tesla MRI scanners. To minimize variation across scanners at different sites, a major effort was undertaken to establish specific standards in the MRI protocol and acquisition parameters. The ADNI MRI protocol was selected in a data-driven manner after considerable deliberation by a group of experts in the field (Jack et al., 2008). A sagittal 3D MP-RAGE sequence was used and optimized for consistency across sites (Jack et al., $2008 ; \mathrm{TR}=2400 \mathrm{~ms}$; $\mathrm{TE}=1000 \mathrm{~ms}$; flip angle $=8^{\circ} ; \mathrm{FOV}=24 \mathrm{~cm}$; final reconstructed voxel resolution $=0.9375 \times 0.9375 \times 1.2 \mathrm{~mm}^{3}$ ). In addition, phantom-based monitoring of the instruments was used to monitor stability over time for each scanner in the ADNI project (Jack et al., 2008). 
Table 2. Demographic and clinical data by genetic subgroups (CLU at rs1532278)

\begin{tabular}{|c|c|c|c|c|}
\hline rs1532278 & $\mathrm{CC}$ & $\mathrm{CT}$ & TT & Total \\
\hline \multicolumn{5}{|l|}{0 APOE $\epsilon 4$ allele } \\
\hline $\mathrm{N}_{0}$ & $148(60)$ & $172(76)$ & $53(19)$ & $373(155)$ \\
\hline $\mathrm{Age}_{0}$ & $76.66 \pm 6.97$ & $76.52 \pm 6.80$ & $74.89 \pm 7.08$ & $76.34 \pm 6.92$ \\
\hline \multicolumn{5}{|c|}{ 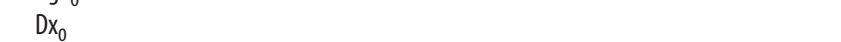 } \\
\hline CON subjects & 58 & 68 & 25 & 151 \\
\hline MCl subjects & 64 & 75 & 23 & 162 \\
\hline AD subjects & 26 & 29 & 5 & 60 \\
\hline $\mathrm{N}_{12}$ & $120(44)$ & $145(66)$ & $48(17)$ & $313(127)$ \\
\hline $\mathrm{N}_{24}$ & $95(41)$ & $112(51)$ & $34(12)$ & 241 (104) \\
\hline \multicolumn{5}{|l|}{$1 \mathrm{APOE} \epsilon 4$ allele } \\
\hline $\mathrm{N}_{0}$ & $103(39)$ & $135(54)$ & $44(18)$ & 282 (111) \\
\hline $\mathrm{Age}_{0}$ & $74.97 \pm 6.16$ & $76.13 \pm 6.24$ & $74.59 \pm 7.24$ & $75.46 \pm 6.38$ \\
\hline \multicolumn{5}{|c|}{ (1) } \\
\hline CON subjects & 20 & 21 & 9 & 50 \\
\hline MCl subjects & 55 & 75 & 23 & 153 \\
\hline AD subjects & 28 & 39 & 12 & 79 \\
\hline $\mathrm{N}_{12}$ & 87 (34) & $111(44)$ & 39 (17) & $237(95)$ \\
\hline $\mathrm{N}_{24}$ & $70(24)$ & $83(31)$ & $30(15)$ & $183(70)$ \\
\hline \multicolumn{5}{|l|}{$2 \mathrm{APOE} \epsilon 4$ alleles } \\
\hline $\mathrm{N}_{0}$ & $33(15)$ & $33(13)$ & $15(6)$ & $81(34)$ \\
\hline $\mathrm{Age}_{0}$ & $73.09 \pm 6.22$ & $71.33 \pm 6.32$ & $70.80 \pm 7.14$ & $71.95 \pm 6.43$ \\
\hline \multicolumn{5}{|c|}{ (6) } \\
\hline CON subjects & 2 & 1 & 1 & 4 \\
\hline MCl subjects & 16 & 17 & 10 & 43 \\
\hline AD subjects & 15 & 15 & 4 & 34 \\
\hline $\mathrm{N}_{12}$ & $28(12)$ & $31(13)$ & $13(4)$ & $72(29)$ \\
\hline $\mathrm{N}_{24}$ & $21(11)$ & $22(8)$ & $12(2)$ & $55(21)$ \\
\hline \multicolumn{5}{|l|}{ Total } \\
\hline $\mathrm{N}_{0}$ & 284 (114) & $340(143)$ & $112(43)$ & $736(300)$ \\
\hline $\mathrm{Age}_{0}$ & $75.63 \pm 6.69$ & $75.86 \pm 6.69$ & $74.22 \pm 7.22$ & $75.52 \pm 6.79$ \\
\hline \multicolumn{5}{|l|}{$\mathrm{Dx}_{0}$} \\
\hline CON subjects & 80 & 90 & 35 & 205 \\
\hline MCl subjects & 135 & 167 & 56 & 358 \\
\hline AD subjects & 69 & 83 & 21 & 173 \\
\hline $\mathrm{N}_{12}$ & $235(90)$ & 287 (123) & $100(38)$ & 622 (251) \\
\hline $\mathrm{N}_{24}$ & $186(76)$ & $217(90)$ & $76(29)$ & 479 (195) \\
\hline
\end{tabular}

Data are sample sizes (number of women) or mean $\pm \mathrm{SD} . \mathrm{N}_{0}, \mathrm{~N}_{12}$, and $\mathrm{N}_{24}$ indicate sample sizes at baseline, 12 month follow-up, and 24 month follow-up, respectively; $\mathrm{Age}_{0}$ and $\mathrm{Dx}_{0}$ indicate baseline ages and diagnoses.

Based on 622 phantom scans collected at 49 sites, the average SDs of scale factors across individual scanners were $0.04 \%, 0.07 \%$, and $0.11 \%$ along the $x$-, $y$-, and $z$-axes, respectively (Gunter et al., 2007). Furthermore, image quality control procedures and postacquisition correction of various image artifacts were performed at a single site (Mayo Clinic) to ensure the consistency of these preprocessing steps (Jack et al., 2008).

Segmentation of the lateral ventricles. For lateral ventricle segmentation, we analyzed baseline $(N=736)$, and 1-year $(N=622)$ and 2-year $(N=479)$ follow-up brain MRI scans from the ADNI cohort. Raw MRI scans were preprocessed to reduce signal inhomogeneity and were linearly registered to a template (using nine-parameter registration). Prior methods for ventricular segmentation have used semi-automated, automated (Chou et al., 2008), and single-atlas or multiatlas methods (Chou et al., 2009). Here we segmented the ventricles with our modified multiatlas approach described previously (Gutman et al., 2013), which was further tested and expanded in two additional analyses (Madsen et al., 2013; Roussotte et al., 2014). Our segmentation approach uses groupwise surface registration to existing templates in addition to surfacebased template blending to yield more accurate results. The lateral ventricles were segmented in each subject using a validated method (Chou et al., 2008). Ventricular surfaces were then extracted from these segmentations and an inverse-consistent fluid registration with a mutual information fidelity term aligned a set of hand-labeled ventricular templates to each scan (Leow et al., 2007). The template surfaces were registered into homologous point-to-point correspondence as a group using medial-spherical registration (Gutman et al., 2012).
To construct a surface boundary for each new subject, a normalized similarity measure (mutual information) between each template image and the new image was computed around each vertex point of each deformed template surface. The position of each new boundary point was defined by the template with the best similarity score, and the final surface was then constrained to be a smooth approximation of this "winner-take-all" construction. This approach is very similar to that of Yushkevich et al. (2010), except that ours is based on surface geometry rather than image voxels. This "patch-based" approach is advantageous compared with whole-template approaches typically used in atlas segmentation, allowing more flexible segmentation, particularly for outliers. Segmentations were assessed visually for defects from multiple views. While visually inspecting ventricular surface segmentations, we removed four subjects (two CON, one MCI, and one AD) whose meshes deviated by several millimeters from the actual periventricular boundaries. Our final analysis included $736 \mathrm{ADNI}$ subjects at baseline, 622 subjects at the 12 month follow-up, and 479 subjects at the 24 month follow-up.

Statistical associations of CLU genotype with ventricular volume expansion. As many previous studies suggested a dominant model of minor T-allele effects (Zhou et al., 2010; Mengel-From, et al., 2011; Ling et al., 2012), here we first compared mean baseline ventricular volumes between $\mathrm{C}$ homozygotes and carriers of 1 or $2 \mathrm{~T}$ alleles, with SPSS version 22.0. We tested general linear models (GLMs) to determine whether genotype at the rs11136000 and rs1532278 loci might be associated with baseline ventricular volumes $(N=736)$, after adjusting for age, sex, and diagnosis (i.e., healthy elderly control, $\mathrm{MCI}$, or $\mathrm{AD}$ ).

As we did not detect an association, we tested additional GLMs to determine whether genotype at these loci predicted ventricular expansion over a period of 2 years, also assuming a dominant model of minor allele effects. In the primary volumetric analyses, GLM outcome measures included difference between total ventricular volume at baseline and volume after 1 year (in cubic millimeters, $N=622$ ) and difference between total ventricular volume at baseline and volume after 2 years (in cubic millimeters, $N=479$ ), controlling for age, sex, and diagnosis. We also introduced a $C L U$ by diagnosis interaction term in the regression models (see Associations between $C L U$ genotype and ventricular expansion).

In post hoc analyses, ApoE genotype (defined as the number of ApoE- $\varepsilon 4$ risk alleles) was introduced as an additional covariate, and we also introduced a $C L U$ by $A p o E$ interaction term in the regression models (see $C L U$ by $A p o E$ interaction). Subsequently, we examined the combined effects of $C L U$ and $A p o E$ genotypes by comparing the trajectory of ventricular volume expansion between carriers of at least one protective allele at both loci ( 0 or $1 \mathrm{ApoE}-\varepsilon 4$ allele and 0 or $1 \mathrm{C}$ allele at rs11136000/ rs1532278), carriers of at least one protective allele at either locus (0 or 1 ApoE- $\varepsilon 4$ allele or 0 or $1 \mathrm{C}$ allele at rs11136000/rs1532278), and participants with two risk alleles at both loci $(2 \mathrm{ApoE}-\varepsilon 4$ alleles and $2 \mathrm{C}$ alleles at rs11136000/rs1532278). As in the primary volumetric analyses, we used GLMs to determine whether the combined effects of CLU and ApoE genotypes predicted ventricular expansion, with change in total volume of the lateral ventricles after 1 year $(N=622)$ and 2 years $(N=479)$ as dependent variables, controlling for age, sex, and diagnosis (see Combined effects of $C L U$ and $A p o E$ genotypes on ventricular expansion). Finally, we used GLMs with the same parameters to examine associations between genotype at rs11136000 and rs1532278 and ventricular expansion separately within each hemisphere (see Ventricular expansion within each hemisphere). As the volume images were already normalized for overall brain size by the nine-parameter affine alignment, additional volume normalization was unnecessary in these analyses.

Surface-based analyses: mapping genotype effects across the ventricular surface. The methods for surface-based image analysis have been detailed previously (Thompson et al., 2004; Ballmaier et al., 2008; Roussotte et al., 2012). The surface models described in Segmentation of the lateral ventricles, above were used. Briefly, a 3D medial curve was computed along the long axis for the surface model of each structure and radial distance measures (distance from the medial core to the surface) were estimated and recorded at each corresponding surface point. These values were used to generate individual distance maps that allowed relationships between genotype and regional ventricular surface 
morphology to be assessed at high spatial resolution in three dimensions. We first examined associations between genotype at the rs11136000 and rs1532278 loci (defined as carrying one or two protective $\mathrm{T}$ alleles vs being homozygous for $\mathrm{C}$ ) and ventricular surface morphology at 12 and 24 month follow-ups.

We also examined the combined effects of $C L U$ and ApoE genotypes on ventricular surface morphology. We compared ventricular surface morphology at 12 and 24 month follow-ups between carriers of at least one protective allele at both loci (zero or one ApoE- $\varepsilon 4$ allele and zero or one C allele at rs11136000/ rs1532278), carriers of at least one protective allele at either locus (zero or one ApoE- $\varepsilon 4$ allele or zero or one C allele at rs11136000/ rs1532278), and participants with two risk alleles at both loci (two ApoE- $\varepsilon 4$ alleles and two $\mathrm{C}$ alleles at rs11136000/rs1532278). Maps in Figures 1 and 2 were corrected for multiple comparisons using a false discovery rate (FDR) of $5 \%(q$ value $=0.05)$. As in the volumetric analyses, age, sex, and dementia status (i.e., healthy elderly control, MCI, or AD) were included as nuisance covariates in all surfacebased analyses. As also mentioned above, since the volume images were already normalized for overall brain size during the nine-parameter affine alignment, we did not further control for total brain volume.

\section{Results}

Volumetric analyses

Associations between CLU genotype and ventricular expansion

Genotype at the rs11136000 and rs1532278 loci was not significantly related to total ventricular volume at baseline $(p=0.276$ and $p=0.203$, respectively), after controlling for sex, age, and diagnosis $(N=736)$. To determine whether genotype at these loci predicted the trajectory of ventricular volume expansion, we examined differences between total ventricular volume at baseline and total volume after 1 year (in cubic millimeters, $N=622$ ) and 2 years (in cubic millimeters, $N=479$ ) in C homozygotes compared with carriers of one or two protective T alleles. As predicted, ventricular expansion relative to overall brain size showed a significant association with $C L U$ genotype.

After 1 year, carrying two $\mathrm{C}$ alleles was associated with greater overall ventricular expansion $(p=0.003$, F-ratio $=$ 9.135 for rs11136000, Table $3 ; p=0.002$, F-ratio $=9.313$ for rs1532278, Table 4), after controlling for sex, age, and dementia status. These associations remained significant at the 2-year follow-up ( $p=0.020$, F-ratio $=5.470$ for rs11136000, Table 3; $p=0.032$, F-ratio $=4.632$ for rs1532278, Table 4). To determine whether the effects of $C L U$ genotype on ventricular expansion were independent of dementia status, we introduced a genotype by diagnosis interaction term in the regression models. We found no significant genotype by diagnosis interaction in these analyses $(p=0.629$ and $p=0.900$ for rs11136000; $p=0.562$ and $p=0.842$ for rs 1532278, at $1-$ and 2-year follow-ups, respectively).

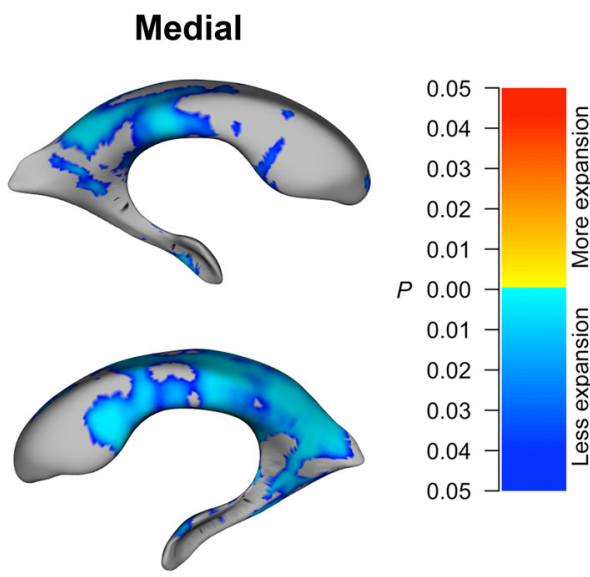

Figure 1. Surface maps depicting the combined effects of rs 1532278 and $A p o E$ genotypes on regional deformations of the lateral ventricular surface at the 12 month follow-up $(N=622)$. Blue-to-light-blue hues indicate regions where carrying more protective alleles is associated with less expansion of the surfaces, after controlling for age, sex, and dementia status. The units on the color bar encode the FDR-corrected values $(q=0.05) p$ values for the observed effects.

Lateral
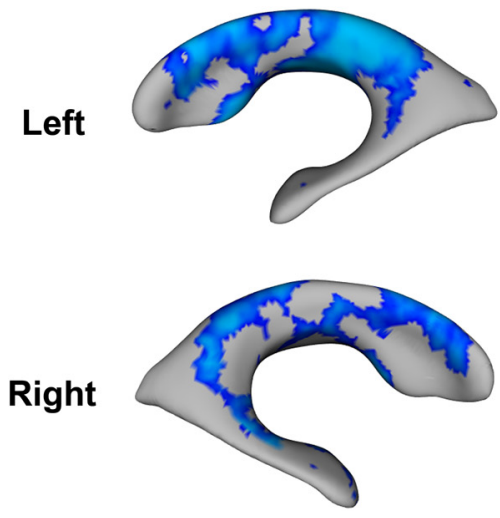

Figure 2. Surface maps depicting the combined effects of rs 1532278 and $A p o E$ genotypes on regional deformations of the protective alleles is associated with less expansion of the surfaces, after controlling for age, sex, and dementia status. The units on the color bar encode the FDR-corrected $(q=0.05) p$ values for the observed effects.

\section{CLU by ApoE interaction}

Carrying $2 \mathrm{C}$ alleles was still associated with greater overall ventricular expansion after introducing ApoE genotype (the number of ApoE- $\varepsilon 4$ risk alleles) as an additional covariate in addition to sex, age, and dementia status, both at 1 -year $(p=0.003$, F-ratio $=9.170$ for rs11136000, Table $3 ; p=0.002$, F-ratio $=9.449$ for rs1532278, Table 4$)$ and 2 -year follow-ups $(p=0.018$, F-ratio $=$ 5.587 for rs11136000, Table $3 ; p=0.027$, F-ratio $=4.937$ for rs1532278, Table 4).

To determine whether these $C L U$ variants affected ventricular expansion equally in participants with zero, one, or two ApoE- $\varepsilon 4$ risk alleles, we added a $C L U$ by $A p o E$ interaction term to the simple additive models containing the independent effects of $C L U$ and $A p o E$. We detected no significant interaction between genotypes at these $C L U$ loci and ApoE- $\varepsilon 4$ loading $(p=0.772$ and $p=0.610$ for $\mathrm{rs} 11136000 ; p=0.731$ and $p=0.660$ for $\mathrm{rs} 1532278$, at 1- and 2-year follow-ups, respectively).

\section{Combined effects of CLU and ApoE genotypes on ventricular expansion}

We then examined the combined effects of CLU and ApoE on ventricular enlargement. We compared the trajectory of ventric- 
Table 3. Results of multiple regression analyses: associations between CLU genotype at rs11136000 and ventricular volume expansion

\begin{tabular}{|c|c|c|}
\hline $\begin{array}{l}\text { rs } 11136000 \\
\text { CC vs CT/TT }\end{array}$ & $\begin{array}{l}\text { Effect of } C L U \text { genotype } \\
\text { (covariates: age, sex, } \\
\text { and diagnosis) }\end{array}$ & $\begin{array}{l}\text { Effect of CLU genotype } \\
\text { (covariates: age, sex, } \\
\text { diagnosis, and ApoE } \\
\text { status) }\end{array}$ \\
\hline \multicolumn{3}{|l|}{$\begin{array}{c}12 \text { month follow-up }(N=622 ; \\
234 C C+388 \mathrm{CT} / \mathrm{TT})\end{array}$} \\
\hline $\begin{array}{l}\text { Total expansion (cubic } \\
\text { millimeters) }\end{array}$ & $\begin{aligned} \text { Fratio } & =9.135^{a} \\
p & =0.003 \\
R^{2} & =0.151^{b}\end{aligned}$ & $\begin{aligned} \text { Fratio } & =9.170 \\
p & =0.003 \\
R^{2} & =0.163\end{aligned}$ \\
\hline $\begin{array}{l}\text { Left expansion (cubic milli- } \\
\text { meters) }\end{array}$ & $\begin{aligned} \text { Fratio } & =7.814 \\
p & =0.005 \\
R^{2} & =0.139\end{aligned}$ & $\begin{aligned} \text { Fratio } & =7.834 \\
p & =0.005 \\
R^{2} & =0.151\end{aligned}$ \\
\hline $\begin{array}{l}\text { Right expansion (cubic } \\
\text { millimeters) }\end{array}$ & $\begin{aligned} \text { Fratio } & =9.541 \\
p & =0.002 \\
R^{2} & =0.149\end{aligned}$ & $\begin{aligned} \text { Fratio } & =9.574 \\
p & =0.002 \\
R^{2} & =0.160\end{aligned}$ \\
\hline \multicolumn{3}{|l|}{$\begin{array}{c}24 \text { month follow-up }(N=479 \\
184 C C+295 \text { CT/TT) }\end{array}$} \\
\hline $\begin{array}{l}\text { Total expansion (cubic } \\
\text { millimeters) }\end{array}$ & $\begin{aligned} \text { Fratio } & =5.470 \\
p & =0.020 \\
R^{2} & =0.230\end{aligned}$ & $\begin{aligned} \text { Fratio } & =5.587 \\
p & =0.018 \\
R^{2} & =0.260\end{aligned}$ \\
\hline $\begin{array}{l}\text { Left expansion (cubic milli- } \\
\text { meters) }\end{array}$ & $\begin{aligned} \text { Fratio } & =5.485 \\
p & =0.020 \\
R^{2} & =0.223\end{aligned}$ & $\begin{aligned} \text { Fratio } & =5.596 \\
p & =0.018 \\
R^{2} & =0.253\end{aligned}$ \\
\hline $\begin{array}{l}\text { Right expansion (cubic } \\
\text { millimeters) }\end{array}$ & $\begin{aligned} \text { Fratio } & =4.716 \\
p & =0.030 \\
R^{2} & =0.212\end{aligned}$ & $\begin{aligned} \text { Fratio } & =4.795 \\
p & =0.029 \\
R^{2} & =0.240\end{aligned}$ \\
\hline
\end{tabular}

${ }^{a}$ In multiple regressions, the $F$ ratio is used to test the hypothesis that the slopes of the regression lines are 0 . The $F$ statistic is large when the independent variable helps to explain the variation in the dependent variable, independently of the other explanatory variables that are regressed out. For instance, here we reject the hypothesis that the slope of the regression line is 0 ( $F$ ratio $=9.135, p=0.003$ ), meaning that there is a significant linear relation between rs 11136000 genotype and total ventricular expansion, independently of age, sex, and diagnosis.

${ }^{b} R^{2}$ is the correlation coefficient based on the corrected model.

ular volume expansion between carriers of at least one protective allele at both loci (zero or one ApoE- $\varepsilon 4$ allele and zero or one C allele at rs11136000/rs1532278), carriers of at least one protective allele at either locus (zero or one ApoE- $\varepsilon 4$ allele or zero or one C allele at rs11136000/rs1532278), and participants with two risk alleles at both loci (two ApoE- $\varepsilon 4$ alleles and two $\mathrm{C}$ alleles at rs11136000/rs1532278). Carrying more risk alleles was associated with greater overall ventricular expansion at the 12 month follow-up ( $p=0.001$, F-ratio $=7.421$ for rs11136000, Table 5; $p=0.001, \mathrm{~F}$-ratio $=7.515$ for rs 1532278 , Table 6$)$ and the 24 month follow-up $(p=0.004$, F-ratio $=5.629$ for rs11136000, Table $5 ; p=0.006$, F-ratio $=5.236$ for rs1532278, Table 6), after controlling for sex, age, and dementia status.

Ventricular expansion within each hemisphere

We conducted additional post hoc analyses to determine whether genotype at the rs11136000 and rs1532278 loci related to the trajectory of ventricular volume expansion within each hemisphere. Carrying two $\mathrm{C}$ alleles at these loci was associated with greater expansion in the left and right ventricles at 1- and 2-year follow-ups, after controlling for sex, age, and dementia status (Tables 3,4 ). These results remained significant after introducing ApoE genotype (the number of ApoE- $\varepsilon 4$ risk alleles) as an additional covariate (Tables 3, 4). Finally, in our analyses of the combined effects of CLU and ApoE genotypes, we found that carrying more risk alleles was associated with greater ventricular expansion within each hemisphere at the 1- and 2-year follow-ups, after controlling for sex, age, and dementia status (Tables 5, 6).
Table 4. Results of multiple regression analyses: associations between CLU genotype at rs1532278 and ventricular volume expansion

\begin{tabular}{lll} 
& & \\
rs1532278 & Effect of CLU genotype & (covariates: age, sex, \\
CC vs CT/TT & (covariates: age, sex, & diagnosis, and ApoE \\
\hline
\end{tabular}

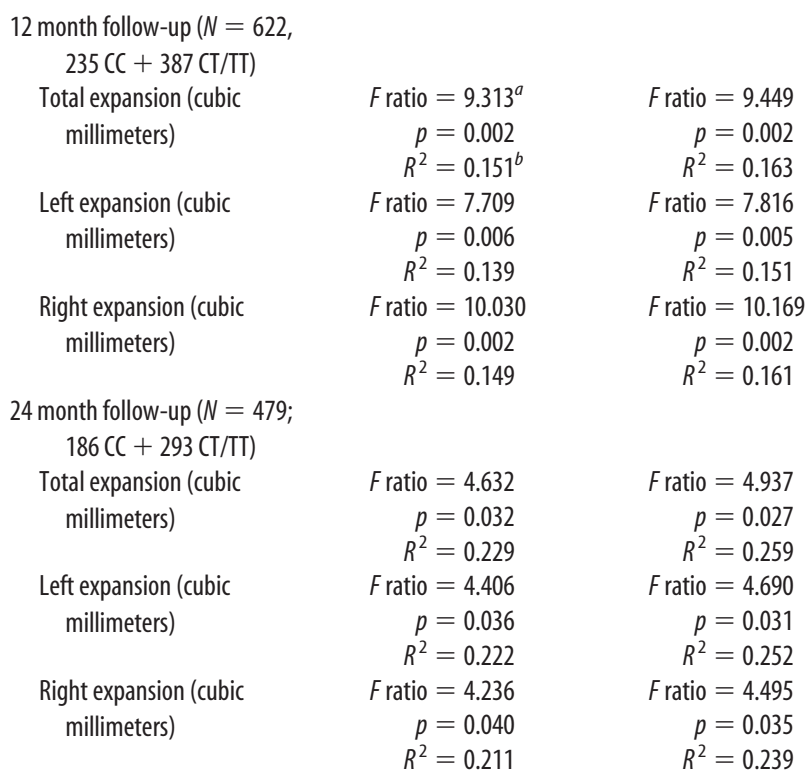

${ }^{a}$ In multiple regressions, the $F$ ratio is used to test the hypothesis that the slopes of the regression lines are 0 . The $F$ statistic is large when the independent variable helps to explain the variation in the dependent variable, independently of the other explanatory variables that are regressed out. For instance, here we reject the hypothesis that the slope of the regression line is 0 ( $F$ ratio $=9.313, p=0.002$ ), meaning that there is a significant linear relation between rs 1532278 genotype and total ventricular expansion, independently of age, sex, and diagnosis.

${ }^{b} R^{2}$ is the correlation coefficient based on the corrected model.

Table 5. Results of multiple regression analyses: combined effects of CLU (rs11136000) and ApoE genotypes on ventricular volume expansion

\begin{tabular}{|c|c|c|}
\hline \multirow[b]{2}{*}{ rs11136000 } & \multicolumn{2}{|c|}{$\begin{array}{l}\text { Combined effects of } C L U \text { and } A p o E \text { genotypes } \\
\text { (covariates: age, sex, and diagnosis) }\end{array}$} \\
\hline & $\begin{array}{l}12 \text { month follow-up } \\
\left(N=622 ; 28^{\prime \prime} 0^{\prime \prime}+\right. \\
\left.250^{\prime \prime} 1^{\prime \prime}+344^{\prime \prime} 2^{\prime \prime}\right)^{a}\end{array}$ & $\begin{array}{l}24 \text { month } \\
\text { follow-up } \\
(N=479 ; 21 \\
{ }^{\prime \prime} 0^{\prime \prime}+197^{\prime \prime} 1^{\prime \prime} \\
\left.+261^{\prime \prime} 2^{\prime \prime}\right)^{a}\end{array}$ \\
\hline Total expansion (cubic millimeters) & $\begin{aligned} \text { Fratio } & =7.421^{b} \\
p & =0.001 \\
R^{2} & =0.159^{c}\end{aligned}$ & $\begin{aligned} \text { Fratio } & =5.629 \\
p & =0.004 \\
R^{2} & =0.239\end{aligned}$ \\
\hline Left expansion (cubic millimeters) & $\begin{aligned} \text { Fratio } & =5.997 \\
p & =0.003 \\
R^{2} & =0.145\end{aligned}$ & $\begin{aligned} \text { Fratio } & =5.836 \\
p & =0.003 \\
R^{2} & =0.233\end{aligned}$ \\
\hline Right expansion (cubic millimeters) & $\begin{aligned} \text { Fratio } & =8.203 \\
p & <0.001 \\
R^{2} & =0.158\end{aligned}$ & $\begin{aligned} \text { Fratio } & =4.734 \\
p & =0.009 \\
R^{2} & =0.220\end{aligned}$ \\
\hline
\end{tabular}

aparticipants coded as " 0 " carried two risk alleles at both loci, subjects coded as " 1 " carried at least one protective allele at either locus, individuals coded as " 2 " carried at least one protective allele at both loci.

${ }^{b}$ In multiple regressions, the $F$ ratio is used to test the hypothesis that the slopes of the regression lines are 0 . The $F$ statistic is large when the independent variable helps to explain the variation in the dependent variable, independently of the other explanatory variables that are regressed out. For instance, here we reject the hypothesis that the slope of the regression line is 0 ( $F$ ratio $=7.421, p=0.001$ ), meaning that there is a significant linear relation between the combined effects of rs 11136000 and $A p 0 E$ genotypes and total ventricular expansion, independently of age, sex, and diagnosis.

${ }^{C} R{ }^{2}$ is the correlation coefficient based on the corrected model.

\section{Surface-based analyses}

Associations between CLU genotype and ventricular surface morphology

In the Associations between CLU genotype and ventricular expansion section, we reported that genotype at the rs11136000 and rs1532278 loci was not significantly related to total ventricular 
Table 6. Results of multiple regression analyses: combined effects of CLU (rs1532278) and ApoE genotypes on ventricular volume expansion

\begin{tabular}{|c|c|c|}
\hline \multirow[b]{2}{*}{ rs1532278 } & \multicolumn{2}{|c|}{$\begin{array}{l}\text { Combined effects of CLU and ApoE genotypes } \\
\text { (covariates: age, sex, and diagnosis) }\end{array}$} \\
\hline & $\begin{array}{l}12 \text { month follow-up }{ }^{a} \\
\left(N=622,28^{\prime \prime} 0^{\prime \prime}+\right. \\
\left.251{ }^{\prime \prime} 1^{\prime \prime}+343^{\prime \prime} 2^{\prime \prime}\right)^{c}\end{array}$ & $\begin{array}{l}24 \text { month follow-up } \\
\left(N=479,21^{\prime \prime} 0^{\prime \prime}+\right. \\
\left.199^{\prime \prime} 1^{\prime \prime}+259^{\prime \prime} 2^{\prime \prime}\right)^{c}\end{array}$ \\
\hline Total expansion (cubic millimeters) & $\begin{aligned} \text { Fratio } & =7.515^{d} \\
p & =0.001 \\
R^{2} & =0.159^{e}\end{aligned}$ & $\begin{aligned} \text { Fratio } & =5.236 \\
p & =0.006 \\
R^{2} & =0.238\end{aligned}$ \\
\hline Left expansion (cubic millimeters) & $\begin{aligned} \text { Fratio } & =5.932 \\
p & =0.003 \\
R^{2} & =0.145\end{aligned}$ & $\begin{aligned} \text { Fratio } & =5.371 \\
p & =0.005 \\
R^{2} & =0.232\end{aligned}$ \\
\hline Right expansion (cubic millimeters) & $\begin{aligned} \text { Fratio } & =8.474 \\
p & <0.001 \\
R^{2} & =0.159\end{aligned}$ & $\begin{aligned} \text { Fratio } & =4.489 \\
p & =0.012 \\
R^{2} & =0.219\end{aligned}$ \\
\hline
\end{tabular}

${ }^{a}$ These subjects were used in the surface-based analyses depicted in Figure 1.

${ }^{b}$ These subjects were used in the surface-based analyses depicted in Figure 2.

"Participants coded as " 0 " carried two risk alleles at both loci, subjects coded as " 1 " carried at least one protective allele at either locus, and individuals coded as " 2 " carried at least one protective allele at both loci.

${ }^{d}$ In multiple regressions, the $F$ ratio is used to test the hypothesis that the slopes of the regression lines are 0 . The $F$ statistic is large when the independent variable helps to explain the variation in the dependent variable, independently of the other explanatory variables that are regressed out. For instance, here we reject the hypothesis that the slope of the regression line is 0 ( $F$ ratio $=7.515, p=0.001$ ), meaning that there is a significant linear relation between the combined effects of rs 1532278 and $A p o E$ genotypes and total ventricular expansion, independently of age, sex, and diagnosis.

${ }^{e} R^{2}$ is the correlation coefficient based on the corrected model.

volume at baseline, but that ventricular expansion relative to overall brain size showed a significant association with $C L U$ genotype at the 1- and 2-year follow-ups. Here, we examined how these $C L U$ variants related to ventricular surface morphology. Consistent with the volumetric analyses, genotype at the rs11136000 and rs1532278 loci was not significantly related to ventricular surface morphology at baseline. However, despite our findings of $C L U$ effects on volumetric measures of ventricular expansion, 3D surface statistics revealed that the effects of CLU genotype on regional patterns of lateral ventricle morphology, after controlling for age, sex, and diagnosis, did not pass FDR correction at the 12 month $(N=622)$ or 24 month follow-up $(N=479)$, perhaps because even this relatively large sample was limited in statistical power to detect very small effects, if present.

\section{Combined effects of CLU and ApoE genotypes on ventricular surface morphology}

In the Combined effects of CLU and ApoE genotypes on ventricular expansion section, we reported that $C L U$ and $A p o E$ genotypes exerted combined effects on ventricular volume expansion. We also compared ventricular surface morphology at the 12 and 24 month follow-ups between carriers of at least one protective allele at both loci (coded " 2 "), carriers of at least one protective allele at either locus (coded " 1 "), and participants with two risk alleles at both loci (coded " 0 "). 3D surface statistics revealed significant (FDR-corrected at $q=0.05$ ) combined effects of CLU and $A p o E$ genotypes on regional patterns of lateral ventricle morphology at the 1- and 2-year follow-ups, after controlling for sex, age, and dementia status. At 12 month follow-up, carrying more protective alleles was associated with less ventricular surface expansion $(N=622$; Fig. 1). That is, the risk alleles were associated with regions of expansion across most of the ventricular surface, especially around the body of the lateral ventricles. At the 24 month follow-up, the same pattern was observed, though the effects appeared slightly less significant than at the 12 month follow-up, consistent with the volumetric analyses (Tables 5, 6), probably because of reduced statistical power resulting from the smaller sample size ( $N=479$; Fig. 2). Figures 1 and 2 illustrate the combined effects of rs1532278 and ApoE genotypes on ventricular surface morphology, and the results were almost identical for the combined effects of rs11136000 and ApoE genotypes (data not shown).

\section{Discussion}

This study is the first to show that the rs 11136000 and rs 1532278 $\mathrm{AD}$ risk variants in $C L U$ are directly associated with altered volumetric measures of longitudinal ventricular expansion within each hemisphere, regardless of dementia status in the elderly. Carrying two $\mathrm{C}$ alleles at these loci was still associated with greater ventricular expansion after introducing $A p o E$ status as a covariate in addition to sex, age, and diagnosis. We found no significant $C L U$ by $A p o E$ interaction, but due to the relatively small number of participants carrying two $\varepsilon 4$ alleles in our sample, we cannot conclude that the weight of these CLU SNPs on ventricular expansion is the same in individuals with different $A p o E$ genotypes. Possible interactions between $C L U$ and $A p o E$ on volumetric measures of ventricular enlargement will need to be further investigated in larger samples including more ApoE- $\varepsilon 4$ homozygotes, such as the worldwide MRI sample now being amassed by the ENIGMA Consortium (http://enigma.ini.usc.edu).

$C L U$ genotype significantly affected the overall volume of ventricular enlargement over time, but the effects of these CLU variants on regional patterns of lateral ventricle expansion did not pass FDR correction at the 12 or 24 month follow-up, after controlling for age, sex, and diagnosis. This does not necessarily suggest that $C L U$ has no effect on the spatial progression of ventricular enlargement. In any thresholded statistical map, one cannot infer that there is no effect in a particular location, as the power can be insufficient to detect it if present. The specific localization of SNP-brain associations is extremely difficult to demonstrate, as statistical power in imaging genetics is often very low, even with the large samples available today. Nonetheless, we recently reported that $A p o E$ status predicted both volumetric and surface-based patterns of ventricular expansion in dementia and normal aging, in the same subjects (Roussotte et al., 2014). This may be because the effect sizes of $A p o E$ genotype on ventricular enlargement were much larger than those of CLU (Roussotte et al., 2014), which is consistent with ApoE- $\varepsilon 4$ being a much stronger genetic risk factor for late-onset $\mathrm{AD}$ than the $\mathrm{C}$ allele at these CLU loci (Bertram et al., 2007), and being involved in the etiology, pathogenesis, and prognosis of many other neurological disorders (Alberts et al., 1995; Friedman et al., 1999; Adamis et al., 2007; Ely et al., 2007). Even so, consistent with earlier reports that clusterin and ApoE share various biological connections and pathways, including a shared set of cell surface receptors (Kounnas et al., 1995), that both proteins affect amyloid $\beta$ (A $\beta)$ deposition and plaque formation (Xu et al., 2000), and that they have additive effects on medial temporal lobe activity even in young adults (Green et al., 2014), our findings demonstrate that the $C L U$ and $A p o E$ risk variants have combined effects on both ventricular expansion and lateral ventricle surface morphology.

Progressive ventricular expansion reflects atrophy of the surrounding gray and white matter (Ferrarini et al., 2008; Qiu et al., 2009). The ApoE- $\varepsilon 4$ allele codes for the ApoE4 protein, which has well documented neurotoxic effects (Mahley and Huang, 2012; Zlokovic, 2013), but there is growing evidence that these CLU variants also lead to changes in clusterin expression, resulting in neuronal dysfunction and degeneration. The $\mathrm{C}$ risk allele at rs11136000 is associated with lower CLU expression (Allen et al., 2012; Ling et al., 2012), reflecting decreased soluble, secreted clusterin protein throughout life (Ling et al., 2012). Clusterin 
exerts neuroprotective effects through many different pathways, including prevention of excessive inflammation, inhibition of apoptosis, clearance of neuronal debris, and potentiation of TGF- $\beta$ signaling (for review, see Nuutinen et al., 2009). In addition, clusterin can bind $\mathrm{A} \beta$ peptides and prevent their fibrillization, and also binds to megalin receptors to enhance the endocytosis of $\mathrm{A} \beta$ peptides and fibrils within glial cells (Nuutinen et al., 2009). In fact, carriers of the $C$ risk allele at rs11136000 associated with lower $C L U$ expression show significantly decreased levels of $\mathrm{A} \beta 1-42$ in the CSF (Elias-Sonnenschein et al., 2013), which indicates the sequestration of $\mathrm{A} \beta$ in amyloid plaques in the brain (Fagan et al., 2006). As ventricular expansion reflects the accumulation of tissue loss in neighboring regions, the multifaceted involvement of clusterin in neuroprotection may underlie our findings that the $\mathrm{C}$ allele is associated with faster expansion of the lateral ventricles, independently of dementia status.

The rs11136000 variant was the top SNP in the original GWA studies (Harold et al., 2009; Lambert et al., 2009) and has been the focus of most subsequent investigations. It is associated with altered CLU expression (Allen et al., 2012; Ling et al., 2012), but it is unlikely to be the regulatory variant. CLU1 and CLU2 are the primary CLU isoforms in human brain, and differ in their first exon and proximal promoter. The rs 11136000 variant is associated with the expression of CLU1 but not CLU2 (Ling et al., 2012). Since rs 11136000 is common to both $C L U$ isoforms, this variant is likely not functional but rather is in high-linkage disequilibrium with a functional SNP more proximal to the CLU1 promoter (Ling et al., 2012). In fact, in a meta-analysis of three large cohorts of $\mathrm{AD}$ patients and control subjects, high-density SNP mapping around this locus mapped the association signal to a more 5' CLU region (Bettens et al., 2012). The strongest evidence for association was found at the rs1532278 locus, which strongly resembles a regulatory element based on sequence alignment of seven species (Bettens et al., 2012). Here, we provide additional evidence that rs 1534478 may be closer to the functional variant, as the association of this SNP with ventricular expansion was slightly stronger than that of rs11136000 in most of our analyses.

ApoE genotyping is considered valuable in clinical trials for Alzheimer's disease and mild cognitive impairment, but growing evidence for both independent $C L U$ effects on brain structure and function and combined effects of $C L U$ and $A p o E$ affecting neurodegenerative processes and the trajectory of brain atrophy, suggest that genotyping these $C L U$ variants may empower clinical trials of dementia. The recent development of simple, costeffective PCR-based techniques to determine these and other variants associated with $\mathrm{AD}$ without the use of expensive instrumentation and reagents (Darawi et al., 2013) should help to facilitate the process. However, our finding that these CLU variants are associated with longitudinal ventricular expansion independently of dementia status, combined with earlier investigations showing that they affect brain structure and function even in healthy young adults (Braskie et al., 2011; Erk et al., 2011; Lancaster et al., 2011) and are more prevalent in patients with other neurological conditions, including schizophrenia (Zhou et al., 2010) and Parkinson's disease (Gao et al., 2011), suggests that their relevance is not limited to $\mathrm{AD}$ and its prodromal states.

These $C L U$ variants seem to affect core physiological processes such as inflammation, immune responses, and $\mathrm{A} \beta$ clearance, which in turn may result in aberrant synaptic development and neurodegeneration. As degenerative brain disorders are often di- agnosed after severe and irreversible neurological changes have occurred, the focus of therapeutic approaches is shifting from the symptomatic treatment of specific conditions to the prevention of neurodegenerative processes. Clusterin is not able to slow down the progression of AD (Nuutinen et al., 2009), but pharmaceutical agents that counteract the effects of these SNPs by raising the expression of clusterin may help to protect the brain before disease onset. Valproate, a histone deacetylase inhibitor that increases $C L U$ expression in human astrocytes (Nuutinen et al., 2010), reduces amyloid accumulation as well as behavioral deficits in mouse models of AD (Qing et al., 2008; Kilgore et al., 2010). Our findings suggest that valproate merits further exploration as it may help to achieve neuroprotection, and contribute to the prevention of dementia and other degenerative brain disorders, especially in carriers of these CLU risk variants.

\section{References}

Adamis D, Treloar A, Martin FC, Gregson N, Hamilton G, Macdonald AJ (2007) APOE and cytokines as biological markers for recovery of prevalent delirium in elderly medical inpatients. Int J Geriatr Psychiatry 22: 688-694. CrossRef Medline

Aisen PS, Petersen RC, Donohue MC, Gamst A, Raman R, Thomas RG, Walter S, Trojanowski JQ, Shaw LM, Beckett LA, Jack CR Jr, Jagust W, Toga AW, Saykin AJ, Morris JC, Green RC, Weiner MW (2010) Clinical core of the Alzheimer's Disease Neuroimaging Initiative: progress and plans. Alzheimers Dement 6:239-246. CrossRef Medline

Alberts MJ, Graffagnino C, McClenny C, DeLong D, Strittmatter W, Saunders AM, Roses AD (1995) ApoE genotype and survival from intracerebral haemorrhage. Lancet 346:575. CrossRef Medline

Allen M, Zou F, Chai HS, Younkin CS, Crook J, Pankratz VS, Carrasquillo MM, Rowley CN, Nair AA, Middha S, Maharjan S, Nguyen T, Ma L, Malphrus KG, Palusak R, Lincoln S, Bisceglio G, Georgescu C, Schultz D, Rakhshan F, et al (2012) Novel late-onset Alzheimer disease loci variants associate with brain gene expression. Neurology 79:221-228. CrossRef Medline

Ballmaier M, Narr KL, Toga AW, Elderkin-Thompson V, Thompson PM, Hamilton L, Haroon E, Pham D, Heinz A, Kumar A (2008) Hippocampal morphology and distinguishing late-onset from early-onset elderly depression. Am J Psychiatry 165:229-237. CrossRef Medline

Bertram L, Tanzi RE (2010) Alzheimer disease: new light on an old CLU. Nat Rev Neurol 6:11-13. CrossRef Medline

Bertram L, McQueen MB, Mullin K, Blacker D, Tanzi RE (2007) Systematic meta-analyses of Alzheimer disease genetic association studies: the AlzGene database. Nat Genet 39:17-23. CrossRef Medline

Bettens K, Brouwers N, Engelborghs S, Lambert JC, Rogaeva E, Vandenberghe R, Le Bastard N, Pasquier F, Vermeulen S, Van Dongen J, Mattheijssens M, Peeters K, Mayeux R, St George-Hyslop P, Amouyel P, De Deyn PP, Sleegers K, Van Broeckhoven C (2012) Both common variations and rare non-synonymous substitutions and small insertion/deletions in CLU are associated with increased Alzheimer risk. Mol Neurodegener 7:3. CrossRef Medline

Braskie MN, Jahanshad N, Stein JL, Barysheva M, McMahon KL, de Zubicaray GI, Martin NG, Wright MJ, Ringman JM, Toga AW, Thompson PM (2011) Common Alzheimer's disease risk variant within the CLU gene affects white matter microstructure in young adults. J Neurosci 31:67646770. CrossRef Medline

Carmichael OT, Kuller LH, Lopez OL, Thompson PM, Dutton RA, Lu A, Lee SE, Lee JY, Aizenstein HJ, Meltzer CC, Liu Y, Toga AW, Becker JT (2007a) Ventricular volume and dementia progression in the Cardiovascular Health Study. Neurobiol Aging 28:389-397. CrossRef Medline

Carmichael OT, Kuller LH, Lopez OL, Thompson PM, Dutton RA, Lu A, Lee SE, Lee JY, Aizenstein HJ, Meltzer CC, Liu Y, Toga AW, Becker JT (2007b) Cerebral ventricular changes associated with transitions between normal cognitive function, mild cognitive impairment, and dementia. Alzheimer Dis Assoc Disord 21:14-24. CrossRef Medline

Carrasquillo MM, Belbin O, Hunter TA, Ma L, Bisceglio GD, Zou F, Crook JE, Pankratz VS, Dickson DW, Graff-Radford NR, Petersen RC, Morgan K, Younkin SG (2010) Replication of CLU, CR1, and PICALM associations with Alzheimer disease. Arch Neurol 67:961-964. CrossRef Medline

Chou YY, Leporé N, de Zubicaray GI, Carmichael OT, Becker JT, Toga AW, 
Thompson PM (2008) Automated ventricular mapping with multiatlas fluid image alignment reveals genetic effects in Alzheimer's disease. Neuroimage 40:615-630. CrossRef Medline

Chou YY, Leporé N, Avedissian C, Madsen SK, Parikshak N, Hua X, Shaw LM, Trojanowski JQ, Weiner MW, Toga AW, Thompson PM (2009) Mapping correlations between ventricular expansion and CSF amyloid and tau biomarkers in 240 subjects with Alzheimer's disease, mild cognitive impairment and elderly controls. Neuroimage 46:394-410. CrossRef Medline

Darawi MN, Ai-Vyrn C, Ramasamy K, Hua PP, Pin TM, Kamaruzzaman SB, Majeed AB (2013) Allele-specific polymerase chain reaction for the detection of Alzheimer's disease-related single nucleotide polymorphisms. BMC Med Genet 14:27. CrossRef Medline

Elias-Sonnenschein LS, Helisalmi S, Natunen T, Hall A, Paajanen T, Herukka SK, Laitinen M, Remes AM, Koivisto AM, Mattila KM, Lehtimäki T, Verhey FR, Visser PJ, Soininen H, Hiltunen M (2013) Genetic loci associated with Alzheimer's disease and cerebrospinal fluid biomarkers in a Finnish case-control cohort. PLoS One 8:e59676. CrossRef Medline

Ely EW, Girard TD, Shintani AK, Jackson JC, Gordon SM, Thomason JW, Pun BT, Canonico AE, Light RW, Pandharipande P, Laskowitz DT (2007) Apolipoprotein E4 polymorphism as a genetic predisposition to delirium in critically ill patients. Crit Care Med 35:112-117. CrossRef Medline

Erk S, Meyer-Lindenberg A, Opitz von Boberfeld C, Esslinger C, Schnell K, Kirsch P, Mattheisen M, Mühleisen TW, Cichon S, Witt SH, Rietschel M, Nöthen MM, Walter H (2011) Hippocampal function in healthy carriers of the CLU Alzheimer's disease risk variant. J Neurosci 31:1818018184. CrossRef Medline

Fagan AM, Mintun MA, Mach RH, Lee SY, Dence CS, Shah AR, LaRossa GN, Spinner ML, Klunk WE, Mathis CA, DeKosky ST, Morris JC, Holtzman DM (2006) Inverse relation between in vivo amyloid imaging load and cerebrospinal fluid Abeta42 in humans. Ann Neurol 59:512-519. CrossRef Medline

Ferrarini L, Palm WM, Olofsen H, van der Landen R, van Buchem MA, Reiber JH, Admiraal-Behloul F (2008) Ventricular shape biomarkers for Alzheimer's disease in clinical MR images. Magn Reson Med 59:260-267. CrossRef Medline

Friedman G, Froom P, Sazbon L, Grinblatt I, Shochina M, Tsenter J, Babaey S, Yehuda B, Groswasser Z (1999) Apolipoprotein E-epsilon4 genotype predicts a poor outcome in survivors of traumatic brain injury. Neurology 52:244-248. CrossRef Medline

Gao J, Huang X, Park Y, Hollenbeck A, Chen H (2011) An exploratory study on CLU, CR1 and PICALM and Parkinson disease. PLoS One 6:e24211. CrossRef Medline

Green AE, Gray JR, Deyoung CG, Mhyre TR, Padilla R, Dibattista AM, William Rebeck G (2014) A combined effect of two Alzheimer's risk genes on medial temporal activity during executive attention in young adults. Neuropsychologia 56:1-8. CrossRef Medline

Gunter JL, Briston PJ, Felmlee JP, Ward CP, Schuff N, Weiner M, Levy J, Jack CR Jr (2007) The ADNI Phantom and Analysis Algorithm: a new and accurate tool to measure scanner performance. Proc Int Soc Magn Reson Med 15:2105.

Gutman BA, Wang Y, Thompson PM, Rajagopalan P, Toga AW (2012) Shape matching with medial curves and 1-D group-wise registration. Paper presented at Biomedical Imaging (ISBI), 9th IEEE International Symposium, Barcelona, Spain, May.

Gutman BA, Hua X, Rajagopalan P, Chou YY, Wang Y, Yanovsky I, Toga AW, Jack CR Jr, Weiner MW, Thompson PM (2013) Maximizing power to track Alzheimer's disease and MCI progression by LDA-based weighting of longitudinal ventricular surface features. Neuroimage 70:386-401. CrossRef Medline

Harold D, Abraham R, Hollingworth P, Sims R, Gerrish A, Hamshere ML, Pahwa JS, Moskvina V, Dowzell K, Williams A, Jones N, Thomas C, Stretton A, Morgan AR, Lovestone S, Powell J, Proitsi P, Lupton MK, Brayne C, Rubinsztein DC, et al (2009) Genome-wide association study identifies variants at CLU and PICALM associated with Alzheimer's disease. Nat Genet 41:1088-1093. CrossRef Medline

Hua X, Hibar DP, Ching CR, Boyle CP, Rajagopalan P, Gutman BA, Leow AD, Toga AW, Jack CR Jr, Harvey D, Weiner MW, Thompson PM (2013) Unbiased tensor-based morphometry: improved robustness and sample size estimates for Alzheimer's disease clinical trials. Neuroimage 66:648-661. CrossRef Medline
Jack CR Jr, Bernstein MA, Fox NC, Thompson P, Alexander G, Harvey D, Borowski B, Britson PJ, L Whitwell J, Ward C, Dale AM, Felmlee JP, Gunter JL, Hill DL, Killiany R, Schuff N, Fox-Bosetti S, Lin C, Studholme C, DeCarli CS, et al (2008) The Alzheimer's Disease Neuroimaging Initiative (ADNI): MRI methods. J Magn Reson Imaging 27:685-691. CrossRef Medline

Jun G, Naj AC, Beecham GW, Wang LS, Buros J, Gallins PJ, Buxbaum JD, Ertekin-Taner N, Fallin MD, Friedland R, Inzelberg R, Kramer P, Rogaeva E, St George-Hyslop P, Cantwell LB, Dombroski BA, Saykin AJ, Reiman EM, Bennett DA, Morris JC, et al (2010) Meta-analysis confirms CR1, CLU, and PICALM as Alzheimer disease risk loci and reveals interactions with APOE genotypes. Arch Neurol 67:1473-1484. CrossRef Medline

Kilgore M, Miller CA, Fass DM, Hennig KM, Haggarty SJ, Sweatt JD, Rumbaugh G (2010) Inhibitors of class 1 histone deacetylases reverse contextual memory deficits in a mouse model of Alzheimer's disease. Neuropsychopharmacology 35:870-880. CrossRef Medline

Kounnas MZ, Loukinova EB, Stefansson S, Harmony JA, Brewer BH, Strickland DK, Argraves WS (1995) Identification of glycoprotein 330 as an endocytic receptor for apolipoprotein J/clusterin. J Biol Chem 270: 13070-13075. CrossRef Medline

Lambert JC, Heath S, Even G, Campion D, Sleegers K, Hiltunen M, Combarros O, Zelenika D, Bullido MJ, Tavernier B, Letenneur L, Bettens K, Berr C, Pasquier F, Fiévet N, Barberger-Gateau P, Engelborghs S, De Deyn P, Mateo I, Franck A, et al (2009) Genome-wide association study identifies variants at CLU and CR1 associated with Alzheimer's disease. Nat Genet 41:1094-1099. CrossRef Medline

Lancaster TM, Baird A, Wolf C, Jackson MC, Johnston SJ, Donev R, Thome J, Linden DE (2011) Neural hyperactivation in carriers of the Alzheimer's risk variant on the clusterin gene. Eur Neuropsychopharmacol 21:880884. CrossRef Medline

Lander ES, Schork NJ (1994) Genetic dissection of complex traits. Science 265:2037-2048. CrossRef Medline

Leow AD, Klunder AD, Jack CR Jr, Toga AW, Dale AM, Bernstein MA, Britson PJ, Gunter JL, Ward CP, Whitwell JL, Borowski BJ, Fleisher AS, Fox NC, Harvey D, Kornak J, Schuff N, Studholme C, Alexander GE, Weiner MW, Thompson PM (2006) Longitudinal stability of MRI for mapping brain change using tensor-based morphometry. Neuroimage 31:627-640. CrossRef Medline

Leow AD, Yanovsky I, Chiang MC, Lee AD, Klunder AD, Lu A, Becker JT, Davis SW, Toga AW, Thompson PM (2007) Statistical properties of Jacobian maps and the realization of unbiased large-deformation nonlinear image registration. IEEE Trans Med Imaging 26:822-832. CrossRef Medline

Ling IF, Bhongsatiern J, Simpson JF, Fardo DW, Estus S (2012) Genetics of clusterin isoform expression and Alzheimer's disease risk. PLoS One 7:e33923. CrossRef Medline

Madsen SK, Gutman BA, Joshi SH, Toga AW, Jack CRJ, Weiner MW, Thompson PM (2013) Mapping dynamic changes in ventricular volume onto baseline cortical surface maps in normal aging, MCI, and Alzheimer's disease. Paper presented at MICCAI MBIA Workshop, Japan. Multimodal Brain Image Analysis-Third International Workshop, MBIA 2013, Held in Conjunction with MICCAI 2013, Nagoya, Japan, September.

Mahley RW, Huang Y (2012) Apolipoprotein e sets the stage: response to injury triggers neuropathology. Neuron 76:871-885. CrossRef Medline

Mengel-From J, Christensen K, McGue M, Christiansen L (2011) Genetic variations in the CLU and PICALM genes are associated with cognitive function in the oldest old. Neurobiol Aging 32:554.e7-e11. Medline

Naj AC, Jun G, Beecham GW, Wang LS, Vardarajan BN, Buros J, Gallins PJ, Buxbaum JD, Jarvik GP, Crane PK, Larson EB, Bird TD, Boeve BF, GraffRadford NR, De Jager PL, Evans D, Schneider JA, Carrasquillo MM, Ertekin-Taner N, Younkin SG, et al (2011) Common variants at MS4A4/MS4A6E, CD2AP, CD33 and EPHA1 are associated with lateonset Alzheimer's disease. Nat Genet 43:436-441. CrossRef Medline

Nuutinen T, Suuronen T, Kauppinen A, Salminen A (2009) Clusterin: a forgotten player in Alzheimer's disease. Brain Res Rev 61:89-104. CrossRef Medline

Nuutinen T, Suuronen T, Kauppinen A, Salminen A (2010) Valproic acid stimulates clusterin expression in human astrocytes: implications for Alzheimer's disease. Neurosci Lett 475:64-68. CrossRef Medline

Pedraza O, Allen M, Jennette K, Carrasquillo M, Crook J, Serie D, Pankratz VS, Palusak R, Nguyen T, Malphrus K, Ma L, Bisceglio G, Roberts RO, 
Lucas JA, Ivnik RJ, Smith GE, Graff-Radford NR, Petersen RC, Younkin SG, Ertekin-Taner N (2014) Evaluation of memory endophenotypes for association with CLU, CR1, and PICALM variants in black and white subjects. Alzheimers Dement 10:205-213. CrossRef Medline

Qing H, He G, Ly PT, Fox CJ, Staufenbiel M, Cai F, Zhang Z, Wei S, Sun X, Chen CH, Zhou W, Wang K, Song W (2008) Valproic acid inhibits Abeta production, neuritic plaque formation, and behavioral deficits in Alzheimer's disease mouse models. J Exp Med 205:2781-2789. CrossRef Medline

Qiu A, Fennema-Notestine C, Dale AM, Miller MI (2009) Regional shape abnormalities in mild cognitive impairment and Alzheimer's disease. Neuroimage 45:656-661. CrossRef Medline

Rajagopalan P, Hibar DP, Thompson PM (2013) TREM2 and neurodegenerative disease. N Engl J Med 369:1565-1567. CrossRef Medline

Roussotte F, Soderberg L, Warner T, Narr K, Lebel C, Behnke M, Davis-Eyler F, Sowell E (2012) Adolescents with prenatal cocaine exposure show subtle alterations in striatal surface morphology and frontal cortical volumes. J Neurodev Disord 4:22. CrossRef Medline

Roussotte FF, Gutman BA, Madsen SK, Colby JB, Narr KL, Thompson PM (2014) The apolipoprotein E epsilon 4 allele is associated with ventricular expansion rate and surface morphology in dementia and normal aging. Neurobiol Aging 35:1309-1317. CrossRef Medline

Stein JL, Hua X, Morra JH, Lee S, Hibar DP, Ho AJ, Leow AD, Toga AW, Sul JH, Kang HM, Eskin E, Saykin AJ, Shen L, Foroud T, Pankratz N, Huentelman MJ, Craig DW, Gerber JD, Allen AN, Corneveaux JJ, et al (2010) Genome-wide analysis reveals novel genes influencing temporal lobe structure with relevance to neurodegeneration in Alzheimer's disease. Neuroimage 51:542-554. CrossRef Medline

Thambisetty M, Beason-Held LL, An Y, Kraut M, Nalls M, Hernandez DG,
Singleton $A B$, Zonderman AB, Ferrucci L, Lovestone S, Resnick SM (2013) Alzheimer risk variant CLU and brain function during aging. Biol Psychiatry 73:399-405. CrossRef Medline

Thompson PM, Hayashi KM, De Zubicaray GI, Janke AL, Rose SE, Semple J, Hong MS, Herman DH, Gravano D, Doddrell DM, Toga AW (2004) Mapping hippocampal and ventricular change in Alzheimer disease. Neuroimage 22:1754-1766. CrossRef Medline

Wijsman EM, Pankratz ND, Choi Y, Rothstein JH, Faber KM, Cheng R, Lee JH, Bird TD, Bennett DA, Diaz-Arrastia R, Goate AM, Farlow M, Ghetti B, Sweet RA, Foroud TM, Mayeux R (2011) Genome-wide association of familial late-onset Alzheimer's disease replicates BIN1 and CLU and nominates CUGBP2 in interaction with APOE. PLoS Genet 7:e1001308. CrossRef Medline

Xu Q, Li Y, Cyras C, Sanan DA, Cordell B (2000) Isolation and characterization of apolipoproteins from murine microglia. Identification of a low density lipoproteinlike apolipoprotein J-rich but E-poor spherical particle. J Biol Chem 275:31770-31777. CrossRef Medline

Yushkevich PA, Wang H, Pluta J, Das SR, Craige C, Avants BB, Weiner MW, Mueller S (2010) Nearly automatic segmentation of hippocampal subfields in in vivo focal T2-weighted MRI. Neuroimage 53:1208-1224. CrossRef Medline

Zhou Y, Wang J, Wang K, Li S, Song X, Ye Y, Wang L, Ying B (2010) Association analysis between the rs 11136000 single nucleotide polymorphism in clusterin gene, rs3851179 single nucleotide polymorphism in clathrin assembly lymphoid myeloid protein gene and the patients with schizophrenia in the Chinese population. DNA Cell Biol 29:745-751. CrossRef Medline

Zlokovic BV (2013) Cerebrovascular effects of apolipoprotein E: implications for Alzheimer disease. JAMA Neurol 70:440-444. CrossRef Medline 